\title{
Coping and Meaning in Everyday Life: Living with Mental Disabilities in Late-Modern Society
}

\author{
Bengt Eriksson ${ }^{1,2}$ and Jan Kåre Hummelvoll ${ }^{1}$ \\ ${ }^{1}$ Hedmark University College \\ ${ }^{2}$ Karlstad University \\ ${ }^{1}$ Norway \\ 2Sweden
}

\section{Introduction}

Studies of the living conditions of vulnerable groups often focus on their actual situation. There is often a description of the way the circumstances of the group in question differ from those of others with respect to health, finances, and their ability to support themselves or make and develop social contacts, i.e., their ability to participate in social life in a similar way to other groups. There is less often a discussion of how long-term changes in the structure and organisation of society affect the living conditions of individuals and groups. Yet long-run societal changes influence everyone's possibilities and limitations and it seems likely that vulnerable groups such as people with mental disabilities are affected to a greater extent than others. There is a risk that groups of people who have a weaker buffer than others with regard to health, social contacts or finances find it more difficult to cope with changes, and are hit harder when changes occur. Organisational changes in health and medical care ${ }^{1}$, economic recessions and structural changes in working life are examples of such changes.

In this chapter, longitudinal societal changes and the everyday conditions of people with mental disabilities are coupled. Recent researchers in social sciences have described how changes in the way individuals are regarded - such as the development of technology and changes in administration and logistics - have together had a great impact. Life today differs from that of 50 years ago in important respects. By means of what has been named 'the process of individualisation', the individual has gradually become the significant social unit. Each and everyone has to a larger extent the possibility to make his or her own choices, but is also responsible for the consequences of the decisions made, whether positive or negative. Previously unknown elements of insecurity have developed, and society has sometimes been characterised as a 'risk society'. Concepts like 'post-modernism' or 'late modernity' attempt to describe this distancing from, but at the same time connection with, the society that developed with the industrial revolution².

\footnotetext{
${ }^{1}$ Studies of changes in psychiatric care, for example, show a class gradient in the changeover from traditional hospital-based institutional care to open, sectorised psychiatry: The latter favoured primarily people from the middle class, while patients with a working-class background found it more difficult to get adequate help (Eliasson \& Nygren 1981).

${ }^{2}$ At the same time, these and similar concepts express uncertainty about the new by not giving it a name of its own (Harste 1999).
} 
An empirical study was carried out to relate these longitudinal societal changes to the everyday life situation of people with mental disabilities. In collaboration with members of a Norwegian user-organisation (Mental Health) multistage focus group interviews were conducted to explore and discuss whether concepts like 'late modernity' and 'risk society' appeared relevant and meaningful.

The way of regarding, and society's support of, people with mental disabilities have changed in a radical way during the last few decades. We describe these changes briefly in the continuation of this chapter and then give a more detailed picture of the long-term and radical, but sometimes fairly invisible, social changes that have been mentioned above. After that we give an account of the empirical work the chapter is based on, first by describing the research model - Co-operative Inquiry - that has been used for data collection and analysis, and then by reporting the participants' experiences of living with mental disabilities in today's society. In a following section the empirical results are discussed in relation to the change in society, on the basis of the following questions: Have concepts like 'late modernity' and 'risk society' explanation value for the understanding of everyday life for a person with a mental disability? Can the characteristics of social change be identified and - if so - how can they be handled? Can development towards a 'risk society' be both positive and negative, imply both (new) possibilities and obstacles? How, in that case, can negative consequences be minimized and new, positive possibilities be taken advantage of and developed? At the end of the chapter the discussion is summed up and we indicate some possible ways of acting in 'late-modern' society.

This chapter thus aims to report and discuss experiences of people who themselves suffer from mental disabilities. By way of conclusion of the chapter we broaden the perspective to some extent to also include professional groups with the task of supporting the mentally disabled, as well as training courses for these groups and research on nursing, support and care. However, here too, the point of departure is the experiences the people concerned have themselves reported. We think that the participation and influence of people with their own experience of mental disabilities should also be a natural and forceful component in professional work, training and research in this field.

\section{Historical review: From stigmatisation to social inclusion - a vision with complications}

People with mental ill-health, mental disabilities or mental diseases are one of the groups that have been paid attention to in public discussions and social policy in the last few decades. The discussions have been both about society's care and support, and about the participation and integration in society of the mentally disabled - or rather their lack of integration and participation. In the 1960s and 1970s a wave of intense criticism of the established psychiatry swept over Europe and the USA (Svensson 2005). Its forms of treatment were described as inhuman, segregating and marginalising. The criticism focused particularly on the ideological function of psychiatry, the tendency to convert an increasing number of human life problems into psychiatric symptoms, as well as its ambition to treat mental suffering on the same basis as physical afflictions, by adopting 'the medical model' (Szasz 1961). According to the critics, mental disabilities were caused by social factors rather than biologically or psychologically based defects in the individual. Scheff (1966) formulated a social-science theory about how mental disabilities develop and consolidate that was based on the labelling and social-role theory. 
During the following decades, the radical criticism of psychiatry was replaced by a reformist period of reform, which can still be regarded as going on. The reforms have been characterised by ideas about normalisation, integration and social inclusion. An early and forceful expression of the change was that the big mental hospitals in many European countries were phased out - the great moving-out (Forsberg 1994) ${ }^{3}$ - a process that is still going on, not least in Eastern Europe. The patients, often committed against their will, were instead to be able to live in their own homes and 'live like others'. The ambition was that people with mental disabilities, instead of being an out-group, separated from society and everyday life, would live their lives in the local community and on as similar terms as others. Besides having their own, personally furnished homes, the possibilities for work, meaningful activities, and recreation, were important components of the individual's everyday life. To the extent that they could not manage on their own, formal and informal support could be offered, by public or private institutions. Nursing and social care would primarily be formed as an offer, and be available in open and non-stigmatising forms. Institutional care, in psychiatric wards, should be available as a last, and normally short, extra support measure.

Forsberg (1992) describes the situation of the 'long-term mentally ill' 4 in a comparative study between Italy, Poland, England and Sweden. The lack of information on Polish conditions makes it difficult to comment on this country, but in all the other countries he finds that it is largely the same deficiencies in societal support that are complained of: There are insufficient resources for non-institutional care and for various forms of intermediate care, e.g. in the form of alternative forms of accommodation, sheltered workplaces or day-care and rehabilitation facilities. The risk of social isolation, as a result of an insufficient social network, is greater for the 'long-term mentally ill' and there is a lack of resources to break it. Granerud and Severinsson (2006) found the same deficiencies in their Norwegian study just over ten years later. Forsberg (a.a.) also points to the fact that collaboration between the authorities did not function satisfactorily, and that the support for the 'long-term mentally ill' was instead mainly suited to people with mild mental problems.

Purely concretely, the reforms of the last 20 years have thus had the aim of giving mentally disabled people a life in their own home, with or without personal support, instead of, as previously, being obliged to live in an institution or in other strictly regulated forms. For many people this has meant changed and improved conditions, even though there are still shortcomings in many ways. The change has largely followed the same pattern in many European countries, but earlier in certain countries than in others.

\section{From a modern to a late-modern society}

The society that developed during industrialism had its roots in the Age of Enlightenment of the $18^{\text {th }}$ century, characterised by a belief in reason, the human being and the new science. The $19^{\text {th }}$ century and the early $20^{\text {th }}$ century saw a radical transformation of society, with

\footnotetext{
${ }^{3}$ 'The great moving-out' alludes to M. Foucault's concept 'the great locking-up'. In his book History of Madness (2006), Foucault describes how large groups were judged abnormal and interned in various institutions in European countries, from the $17 \mathrm{th}^{\mathrm{h}}$ century and onwards. A development that was only seriously reversed by the de-institutionalisation that was started in the years after the Second World War.

${ }^{4}$ This expression is used by Forsberg and therefore also in the text that describes his research.
} 
industrialisation and mass production, often according to the principle of the conveyor belt'. In many countries an urbanisation process was started, from a poor agrarian society to a more urbanised and richer one. Modern society developed, not least in Europe and the USA. Working life was modernised, housing was improved. Society developed and prosperity increased rapidly. Functionalism, a trend that characterised important fields in social life, agreed well with the prevalent belief in progress, growth and development. The modern project also included welfare. Health and medical care, education, care of the elderly and groups that could not support themselves on account of handicaps/disabilities it was all an expression of the idea that the general welfare should include the whole population. In many countries, not least in Scandinavia, a strong state apparatus to administer and produce welfare services was developed. In other countries the responsibility was placed on separate organisations, working life or family, but in close cooperation with the public sector.

At all events we have to a certain extent left the society of modernity behind us. The vision of society that lay behind the industrial society and the modernisation process can no longer be completely used as a description model for the stage of development in which we now find ourselves. Modern society's secure anchoring in the belief in growth and increasing material prosperity to share is wavering gravely. We are in a different stage of development. Many researchers think that this differs on such decisive points from the industrial society that it ought to have a different name. It is in this connection that concepts like 'latemodernism', 'post-modernism' or 'the second modernity' have been used. They all aim to describe a change from the previous industrial society, without therefore having to define the coming one, the post-industrial one. The concept of the 'risk society' also refers to the stage of society that we now find ourselves in, but wants to focus on one aspect of this society, namely its connection with the partly new and different risks and insecurities created by the development itself. The fact that we have chosen in this text to use 'latemodernism' is more an expression of our desire for a broad and generally applicable concept than criticism of other, closely related, terms. In our description of the late modernity society we also include quite a few factors that have been paid attention to in the discussion of the risk society - since they have a special relevance to vulnerable groups and their life situation.

The characteristics of the late modernity society include processes like globalisation and an economy that does not know any national or geographical boundaries. Service production increases and a greater and greater proportion of the workforce are occupied with services. The role of the mass media grows. Communication technology is increasingly important and constitutes one of the strongest forces in society - we need only mention the role that mobile phones and the Internet have recently played in national changes in society in North Africa. The big visions of society, the big stories, are challenged - maybe the age of the big stories is over. Power is in many places and more difficult to identify. Society has become more 'invisible'. It is also characterised by the fact that threats and risks affect both society and the lives of individuals to an increasing extent. They can be industrial risks or environmental threats, but also risks produced in and by the abstract, often worldwide, systems that more and more manifestly also influence the everyday life of the individual. The recent accident at the nuclear power station at Fukushima can be seen as an example of such environmental catastrophes. We do not yet know what consequences it will have, and accidents of this kind are of course always unique. But a comparison can be made with the 
nuclear power accident at Chernobyl in 1986, which had consequences that extend right up to our day. The risks in today's society thus tend to be global. Terror attacks of previously unknown dimensions can strike anyone, in principle anywhere in the world. A society's electricity supply can be knocked out by some abstract fault very far away. Speculation against a country's currency by unknown forces can have disastrous consequences for the finances of the individual.

These and similar new risks cause the term risk society to be used to denote this society after modernity - a name that was to be established with great impact by Ulrich Beck's epoch-making work Risk Society - Towards a New Modernity (1992) ${ }^{5}$. Beck has, however, later himself questioned this term. Perhaps it should rather be said that there is a new kind of insecurity or danger that characterises the society of our time - and perhaps of the future.

The traditional risks of the industrial society were to a much greater extent local, visible and possible to take care of. Modernisation's emphasis on reducing and eliminating risks in working life, social life and private life, for example by means of work-environment measures, traffic-safety work and an extensive social policy, were intended to realise the vision of "the good society". In a certain sense the industrial society's emphasis was on "conquering nature" ("the end of nature"), for example by converting natural resources into useful products. The fight was between man and nature. The insecurity involved in being exposed to unpredictable nature would gradually be overcome by means of technology and science.

In the society of our time, it is instead - to a certain extent - man's own products, the results of development, that constitute threats. The threats are man-made; Beck and Giddens speak about "manufactured uncertainty" (Beck, 1998; Giddens, 1996). It is these "cultural products" - results of the technical and economic development itself - that create risks and make society vulnerable. The uncertainty that unpredictable nature could constitute has largely been overcome - human beings have tamed nature - but has been re-created in the unpredictability of the culture. Beck (1994) speaks about "the return of uncertainty to society". Modernisation's faith in science's ability to solve global, national and individual problems, to create the good life, has struck back: Science solves many problems but also creates new ones. The optimism of the industrial society has been replaced by reflexive modernisation.

In this society the individual has been made distinct in a completely different way than previously - a process that has gone on for a long time. Nowadays we must as individuals continually create and re-create our social existence - one speaks about social reflexivity. While collectively steering traditions and rituals in the previous society often also functioned as direction guidance for the various attitudes of the individual, these must nowadays to a far greater extent be formed by the individuals themselves. These choices are now instead guided by reflexive consciousness, considerations and consequence assessments in the light of their own lives. Guidance is not taken from over-individual beliefs but from people's own life history. To "realise one's life project" or to "pin one's faith on oneself" have become established slogans that in the spirit of individualisation express social reflexivity in terms of positive possibilities. At the same time, it is evident that distinctions between individuals and groups are tending to increase even more, for example between social classes or groups with different educational backgrounds. Individuals are

${ }^{5}$ Original title: Risikogesellschaft: Auf dem Weg in eine andere Moderne (1986). 
quite simply left more to their own resources in the form of material assets, social networks, knowledge, social competence and image of themselves.

Security and safety were to pervade the modern society, closely connected to hightechnological production, an efficient economy and a positive view of the possibilities of science. The society that is now developing, the second modernisation (Beck, 1992), means that the question of society's possibilities to create security and safety, and to inspire confidence in important respects has changed.

Questions of trust and confidence are thus closely connected to the successive transition from an industrial society to a late-modern society characterised by global movements, technical and economic as well as political and cultural. Trust based on spatial closeness, personal acquaintance and cultural similarity is replaced by trust in anonymous expert systems that the individual has very little knowledge of but is nevertheless obliged to trust. Giddens (1996) speaks here about the "transformation of intimacy" from trust based primarily on personal acquaintance - trust in a person - into trust in relation to abstract systems - trust in a system. He uses the term "disembedding" to describe this change in social relations. Disembedding means that the relations are removed from their ontological connection and become abstract and impersonal. Living in late-modern society involves demands for acceptance and trust without (always) being able to view the whole situation and comprehend. The individual is obliged to trust the competence of the expertise just in its function of expertise. Trust is established for abstract systems rather than for individual and well-known people. Abstract systems like bank services, telecommunications, electricity supplies or booking systems for train tickets, for example, are what first come to mind, but it is not too far-fetched to also exemplify with the expert systems for nursing and care that are built up within the framework of social policy. As representatives of the systems, nursing and care staff have a central task to re-create trust in these abstract systems. Giddens (1996) speaks here of re-embedding, which implies that the abstract expert systems are reconnected to the local connection. This re-connection, which is of decisive importance for the establishment of a new form of trust, under the conditions of late modernity, is of two kinds (Giddens, 1996): facework commitments and faceless commitments. An ordinary visit to the doctor can serve as an example of both forms of contact: the doctor represents a facework commitment, a personal contact, but is at the same time a representative of the unsurveyable field of experts that medical care today constitutes for the individual. The medicine order that can be the consequence of the visit to the doctor is controlled by an administration, logistics and dispatch that are not represented by any individual person that the patient can establish a relationship with (as is the case in some sense with the doctor). The handling of the medicine can therefore be regarded as a faceless commitment.

Against this background, it is of great interest to investigate how a group that is considered exposed, people with mental disabilities, experience, think and behave in a late-modern society such as for example the Norwegian.

\section{Method: Creating knowledge in co-operation}

The aim of the study was to investigate whether the theory of 'risk society' was considered relevant when related to the experiences of everyday life of a group of persons with mental health disabilities who regularly attended a user-run centre (the Centre) in a middle-sized Norwegian town. The research questions dealt with the following themes: In what way are the 'risk society', and the underlying process of individualisation materialised in everyday 
life? How can the consequences of this societal development be handled and mastered both individually and collectively?

We chose co-operative inquiry as our research design. This mode of inquiry has its roots in action research and has a holistic and humanistic basis (Rowan, 2006). Co-operative inquiry emphasises the active influence and participation of all partners in the research process, from the beginning to the end of the research. Researchers and co-researchers (i.e. participants) constitute a 'community of inquiry' with mutual responsibility for development of knowledge. The value basis of this research approach is expressed quite precisely by Peter Reason (1994):

Human inquiry practitioners assert, in contrast to the positivist world-view, that we can only truly do research with persons if we engage with them as persons, as co-subjects and thus as co-researchers: hence co-operative inquiry, participatory research, research partnerships, and so on. And while understanding and action are logically separate, they cannot be separated in life; so a science of persons must be an action science. I use the term human inquiry to encompass all those forms of search which aim to move beyond the narrow, positivistic and materialist world-view which has come to characterize the latter portion of the twentieth century. While holding on to the scientific ideals of critical self-reflective inquiry and openness to public scrutiny, the practices of human inquiry engage deeply and sensitively with experience, are participative, and aim to integrate action with reflection. (p. 10)

Thus, co-operative inquiry is relevant when investigating local knowledge and experience from those who are directly involved, and thereby increases the possibilities of developing relevant knowledge. In can be maintained that there are likenesses between this research strategy when approaching the empirical field and the general development towards a latemodern society characterised by greater elements of individual responsibility, participation and a lesser trust in experts - also concerning research and developmental work.

Data collection and analysis: The dialogical nature of co-operative inquiry fits well with multistage focus group interviews as a method for data collection (Hummelvoll 2008). Therefore, this variant of focus group was chosen in this study. The multistage focus group is characterised by the same group exploring a certain problem, theme or phenomenon through several meetings. The method could be conceived as inquiring knowledge dialogues that focus on experiential material. Through these dialogues, there are possibilities to 'elevate' the participants' experiences to a higher level of abstraction. Thus, the potential utility value of the knowledge exceeds the concrete situation in which it is created.

In multistage focus groups, the researcher functions as moderator and leads the knowledge dialogue throughout the whole process. The researcher decides the theme of inquiry and then successively elaborates on it together with the participants. Compared to traditional focus group interviews, the group feeling establishes itself through both interaction and increased knowledge of each other. A calmer atmosphere than if 'all things' should be said in only one interview session often characterises the inquiry. Consequently, the focused theme is gradually enriched by adding new perspectives and nuances by means of examples from everyday life (or practice) and experiences made in the period between the interviews. Additional meetings contribute to exploring experiences and counter-experiences. This presupposes development of trust amongst the co-researchers (i.e. the participants), appreciation of divergent views and staying open-minded by allowing one's own views to be put to the test. 
An essential feature of multistage focus groups is that the persons participating in the first group sometimes change in subsequent meetings. This happens because the inquiry process extends over a period of time and hence some of the original participants may be unable to attend following meetings. Therefore, one or two new members can join the group in the second or third session. This has proved to be an asset because alternative opinions or perspectives of the new members can challenge the group effect marked by more or less pressure against consensus (Hummelvoll 2008). Thus, the group dynamics may be stimulated and the inquiry vitalised by deepening the understanding of the focused theme. However, in order to secure the continuity of the group, it is important to keep the group size so large and stable that the core process of knowledge development is maintained.

In our study the participants consisted of the research group (two researchers and one user representative employed by the University College) and members of the user-organisation Mental Health who regularly attended the Centre. The focus group met three times during the autumn of 2008, with - apart from the research group - eight, five and four participants, of 20 to 60 years of age, both men and women. Each interview lasted about two hours. Immediately following the first two interviews, a summary was made and a preliminary analysis carried out, which were presented and commented upon at the beginning of the following focus group. The interviews were recorded and transcribed verbatim. A qualitative analysis as an empirically led content analysis (Malterud 2003) was carried out: The entire data material was read repeatedly; meaning units were coded and grouped together under preliminary themes, validated in relation to data, and finally the main themes from the inquiry process were created. Then the results of the analysis and interpretation were presented at an open meeting at the Centre. Guided by comments from the participants at this meeting, the analysis was finalised and published as a research report (Hummelvoll, Eriksson \& Beston 2009) and later as a peer reviewed article (Eriksson \& Hummelvoll 2011 - in press).

Ethical considerations: Ethical aspects were taken care of by presenting the theme and design of the study to the Board of the Centre, from which the research was sanctioned. The written information was discussed with the board members before it was distributed to potential participants. Participation in the focus groups was voluntary and written informed consent was obtained from the participants. None except the research group and the coresearchers had access to the data. The principles of the Declaration of Helsinki (World Medical Association 2002) - autonomy, beneficence, non-maleficence and justice - were taken into account in all parts of the study.

\section{Results: Coping and meaning - everyday life in today's society}

The thematic analysis of the material from the multistage focus group interviews resulted in five overriding themes, namely, change and uncertainty; mental disabilities and societal obstacles; the technological dominance; individualisation and loneliness; searching for a meaningful everyday life. These themes are described and deepened in the following text and exemplified with quotations from the focus group interviews.

\subsection{Change and uncertainty}

Society is changing at a fast pace which have impacts on the concrete level as well as on the abstract level. The familiarity of the local community has partly been replaced by a society which is difficult to comprehend and which creates feelings of alienation: 
- What we are talking of now - the 'risk society' - isn't something new. It has probably to do with a process of alienation...

- There has been a distinct change since I was a kid. Earlier you could pop in to your neighbour for a brief visit. The doors were open. Now this has changed. You have to make an appointment if you are going to visit somebody. Why is it so?

- We are living in a cold society, where the chill is eased with tranquillizers.

- It is demands on efficiency that characterise life in so many areas.

The emphasis on efficiency and busyness seems to lead to meetings between people being more superficial and anonymous:

- There has become a lot of anonymity: We don't meet as people.

- Yes, there is anonymity in society as a whole and in everything official: Quickly in the door and fast out again and as cheap as possible.

Swift changes and demands for readjustment in a variety of areas create an experience of uncertainty and insecurity. The ongoing changes which we have to face awaken a longing for a safe basis for one's orientation in the world:

- Insecurity...it is difficult to make an enduring platform because things are constantly changing... You meet demands to adjust and be able to deal with all the new things that arise.

- Yes, everything goes so quickly - and so quickly in such a wide area: We meet people with different languages; Technology develops and dominates; the village used to be a limited area but now the boundaries are gone - I think of globalisation. The Internet for example - there the language is English.

- The village as a clearly defined and manageable unit has changed now in relation to a world around without boundaries. You can lose your sense of direction.

- Yes, there is nothing you can make a map of...

One aspect of the societal development is the lack of time and the increase of stress:

- Our time is stressed. We have to make the best of the fifteen minutes we get from the doctor, and it is difficult to say all that you have been pondering on for a long time. If you have two things on your mind, then you have to make a new appointment for the second one. It was easier when I could just drop in at the doctor's office. With my problems I have enough with today and tomorrow - I can't plan for a long time ahead.

A specific phenomenon in our daily life is all the music that encroaches on people in shopping centres or as "waiting music" when making phone calls. This "sound bombardment" may be conceived as difficult to endure for people with mental disabilities:

- It is hard to stand all the sound. Hasn't this to do with protection of privacy?

- I love music and make active choices for myself. But music is used everywhere in order to sedate and ease. Is it so that silence is embarrassing? I find quietness good now and then. But many people have hectic days, and these things are forced upon us - music that we don't want to have. Yes, I think we are living in a kind of terror world - and therefore we have things that sedate us everywhere.

- Perhaps music replaces some of the real contacts between people?

\subsection{Mental disabilities and societal obstacles}

Mental disabilities are connected with relationships between the individual and society which defines the individual person's difficulties. Disabilities are experienced in society and in relation to not being able to cope with necessary daily tasks. Thus, disabilities are connected with the individual person's life in the community. However, defining mental disability is not easy. One of the participants highlights two solutions related to well known challenges: 
- If a person chooses to avoid using the bus at times when it is usually crowded, and instead chooses quieter periods of the day - is this then a disability? What about shopping food on Monday morning instead of shopping when it is crowded and busy. Is this then a functional deficit? Does it only become a hindrance when it obstructs you from doing the things you otherwise would have done if you were "free"?

The participants maintain that many people with mental disabilities have problems related to their weak financial situation:

- It is expensive to be poor. Lacking means makes you "fall off" and become excluded...

- You must do everything in the right way. Then everything works. If you need help, perhaps there aren't people...

- Or that information and help cost money. Services cost money and they cost more for those who don't have much!

- $\quad$ People with ailing finances and mental health problems are therefore doubly exposed.

The relationship between society and persons with mental disabilities is often problematic. Societal institutions are experienced as somewhat abstract and impersonal. Mental disabilities may in one aspect be considered as created by society - like "manufactured societal hindrances":

- We don't get more information than the caseworker tells you. Earlier our rights were not so complicated, and there was personal knowledge. The doctor knew the members of the local rural community.

- $\quad$ The officials also don't tell us about all the things that are available. There are so many possibilities for help now. But they are not so quick to inform us. It is the officials that decide what you shall have, and you are dependent on the official ... The website of $N A V^{6}$ is incomplete. So societal hindrances are produced. We are dependent on the officials and vulnerable.

- If your application is incomplete on one point, or there is a paper missing, they send the whole application back instead of pointing out what was missing and asking to get just that.

One aspect of these hindrances is "the rule of the red tape", which is about the superfluity of forms that society demands that you know and can handle in order to take care of your rights and to get access to help. In a more abstract meaning this has to do with fitting into the definitions and the right categories.

- Many people have a phobia about forms, and have great problems to understand the wording and the kind of answers that are expected in the various columns and boxes. It is difficult and embarrassing to ask for help to fill in - and it will have major consequences if you don't do so.

- The various services should have a low threshold and not be so run by systems. The waiting time for getting help is quite often long... In acute psychiatry the problem is whether you fit the criteria or not - and if you are so-called 'amendable to treatment' according to the form.

When meeting the public, trust in the social services is put to the test. Stability and coherence in relationships are needed in order to promote trust, and the caseworker must be worthy of trust. When meeting public representatives, several factors seem to create distrust:

- You don't get trust in eight different people. Trust must be built over time.

- Sometimes I think that "the systems" have shown me very much distrust through letters and threats ...you have to fulfil requirements and you must justify and document everything. The whole system is founded on distrust, and then it is difficult for me to show trust in return.

\footnotetext{
${ }^{6} \mathrm{NAV}$ is an abbreviation for The Norwegian Labour and Welfare Administration
} 
The possibility of having work and developing work-life integration is part of society's political objectives - also for persons with mental disabilities. However, many have experienced problems when applying for supported employment:

- We have an official policy about integration and universal arrangements. Nevertheless, there are more persons outside the labour market now than before - even though the Norwegian economy is really thriving... What can the reasons be?

\subsection{The technological dominance}

Mastering the new technology - computer technology in particular - contributes to social inclusion, but those who, for various reasons, are unfamiliar with the technology experience themselves as excluded. Authorities and social organisations expect most people to be connected to the Internet - or at least have access to the Internet. Some of the functional obstacles that people experience are therefore related to lack of knowledge concerning how to use computer technology. Consequently, the question is whether one copes with the technology - or feels ruled by it.

- Things are more accessible - only one press on the button away - but at the same time more closed for those who don't have the knowledge or the facilities.

- Try to find your way to the right form on the NAV site... Yes, you must know the name of what you want. You have to know it.

- I asked to have a form but was told to go to the Net and fetch it. I felt that it was weak to say "I don't know how"... so I said thank you and left - without a form.

- Yes, knowledge is necessary to make your way in society. If you lack knowledge you will easily be outside and powerless. If you have knowledge, you are inside.

The participants wish to be involved when public websites are being developed so that they will be user-friendly. It is necessary to get access to relevant information in order to be able to choose. However, help is increasingly needed to find what they are searching for.

There are positive aspects of computer technology as well: personal blogs can be used as a means of building one's identity and to make a profile of interests and competence. One can create one's own identity. The blog may also function as an open diary that many people can follow and stay updated.

- On the Internet you can become who you want. What is different and good is that you can throw out people when you want to, and that is not possible when they are sitting on your sofa at home.

- And you needn't disclose more than you decide on the Web. In personal interactions you disclose more of yourself because we see each other - we notice the facial expressions...

\subsection{Individualisation and loneliness}

Individualisation is a prominent feature of the societal development. This implies that the responsibility today to a large extent relies on the individual when it comes to questions which in earlier times could be handled within the framework of the family or other collectives. The individual is more free, but at the same time more responsible. There is also a paradox here: On one hand the individual is to create his or her own life and be responsible, while on the other hand one is expected to go with the stream - i.e. to be like others expect 'people' to be:

- Everybody is supposed to follow the mainstream. This is more important now than before. 
- Hasn't it always been like this?

- Yes, but the problem is that there are so many streams to follow.

- Individualisation is focused, but nevertheless you have to fit into social expectations. Consequently, there are no real options if you deviate from the mainstream. You get a loser stigma if you have mental problems or problems with drugs.

One aspect of individualisation and societal rationalisation is that the concrete contacts between professionals and users are reduced. Thus, when the face-to-face contacts between the parties are replaced by automation, the impersonal feature of daily life becomes even more prominent. When the development is characterised by automation and anonymity instead of personal contacts, the feeling of loneliness arises:

- I think of the 'terror society' - we are afraid of the neighbours and are sceptical towards them. The 'risk society' is marked by loneliness. This is also shown in user research, using the method "User asks user". In this study the biggest problem was loneliness - and with loneliness other problems followed...

- 'Risk society' ... yes, we are lonely - and there are constantly new things we have to learn and respond to - simultaneously.

With individualisation follows increased demand on the ability for self-presentation, i.e. being capable of speaking for oneself and not leaving it to experts or administrators. Being able to express oneself also involves believing that what one says is worth listening to and experiencing acknowledgement from others - and finally being able to realise that this is true. When one is able to participate in the conversation or discussion, a feeling of being significant may grow. But it is also a right to remain silent if the theme of conversation is unfamiliar.

\subsection{Searching for a meaningful everyday life}

Dealing with daily duties and creating a meaningful life are vital to persons with mental disabilities as well as for others. Societal developments present opportunities in that direction. This presupposes having a network of persons who support you and who you feel a spirit of community with. Adapted work conditions can contribute to mastery and meaning. Possibilities exist, but are not sufficiently utilized:

- It is up to the individual. A disabled person can participate if the work situation is tailored. Nowadays, people can work at home - the options are multiple and flexible if they are used. But this flexibility isn't utilized.

- $\quad$ There are a lot of tasks or jobs which don't require sitting in an office. But it depends on having computer tools and equipment and being trained in computer skills. People with disabilities must be upgraded, they must receive training and they need help...

- People want to get into jobs and be part of working life. It is healthy. But people are medicated too quickly, thus covering up the problems. The pills serve as a chemical lid over what is difficult.

In order to participate in society, e.g. by having a job, the support systems should to a larger extent focus on helping the individual to cope with daily tasks despite problems and disabilities:

- I think that one should be better at learning how to live with one's shortcomings, and learning to live better with oneself. Everybody has faults, nobody is perfect.

Belonging to an alternative fellowship: When the public service and support systems cannot provide practical assistance to solve problems, it is important to have access to alternative arenas and fellowships that make it possible to learn from others who are in the same life situation - and to be able to try out new modes of being, new problem-solving 
strategies in a supportive milieu. The Centre is an example of such a milieu. It constitutes an alternative fellowship characterised by a low threshold service for work and activities - and in addition serves as a competence centre for user involvement. Participating in the community of the Centre gives support to daily coping and provides meaningful experiences. Here one can "be oneself" in an accepting environment:

- You are yourself when you arrive - you are accepted as long as you don't hurt anybody. You may come and just sit and look around, and you may take part in preparing meals or renovating the house.

- The building is being renovated. You can also go on a trip or go for a walk in the town. We also have a football team here, and we go on summer tours. So there is something for everyone ...

- But the Centre must not contribute to passivity. It is a place for growth and being - a place to be, to learn and to recover when it is needed. It is not meant to be a replacement for school attendance. Here, it is possible to recover - yes, recover - that is the right angle. The basic values of the Centre are trust, user management and appropriate care. It is not treatment-but action focused.

Expectations and demands: Expectations on the individual are that one contributes "such as one is" and with "what one can". This means on the one hand acknowledgement and recognition, and on the other that fellowship norms are accepted.

- Your religious belief is not an obstacle to being here either, but it is basically nothing we talk about much. If you want to talk about religion you can do so, but you can't stand and talk in front of the whole assembly. Religion is a private matter. But otherwise people can come as they are.

In addition to the requirement not to hurt others, there is another demand and a permanent hindrance from using the Centre:

- The requirement for being here and using the Centre is: Not to be drunk or have a hangover. But you are not excluded, but just sent home! "You are warmly welcome back when you are sober".

Trust and care: The Centre is regarded as an addition to other services offered in the local community. This means that the participants can have treatment relations or work/activity offers besides the Centre. Therefore one can come "home" to the Centre - home to a fellowship that is like a good family. In the description of the atmosphere and culture, one participant chooses "greenhouse" as a metaphor. The culture in the greenhouse has been influenced by the fact that it is a different place where basic values are trust, user management and adapted care. Trust is shown in many ways, but very concretely in that 13 people have been given keys to the house. Importance is attached to there not being guardianship, but user management.

- People decide themselves whether they feel that the place is something for them. They find out by coming to visit - walking around a bit - seeing how they feel. But it is like that everywhere: Not everyone fits in to every place. The most important thing is that they choose the Centre - or not. There are qualities here that are not experienced in the community.

- What are the qualities of the Centre here?

- Just look round here: It's the people! Here things are steered by the users.

- A low degree of control characterises the relations here - and it is just that which is missing in the public helping services. There - there are agreements and rules and they are stuck in their structures. Here it is different.

- I have had some problems with drugs and such things. In other places there has been a focus on negative talk, but here I have been given a golden opportunity for ordinary talk. And I can also 
be here late in the evening, at the weekend - and when I myself may want to. I can work, cook and be together with the other users of the place.

The adapted care, which nobody can manage without, is a question of caring about and caring for others. In the focus group discussions, this finds expression in the following reflections:

- You don't need treatment when you are taken care of!

- $\quad$ No, you feel the caring atmosphere.

- Yes, here we are met in a genuine way. For example, we mean it when we ask: How are you now? We understand each other without having to make long explanations.

- And if there is a day when you don't see someone who is usually here, you ask how that person is today. It is care that it is a question of.

The Centre is different and unique because it is not an institution, and because it is a place with a fellowship that each person chooses to be part of. In this way, the Centre constitutes an essential part the participants' network. Here, they get information, understanding and suggestions for how to cope with the challenges and possibilities of everyday living in the local community.

\section{Discussion}

\subsection{Co-operative inquiry - a fruitful way of producing knowledge about everyday life?}

The model that was used in this study to increase knowledge about what it is like for people with mental disabilities to live in late-modern society - co-operative enquiry - is characterised by co-operation, flexibility and dynamics. It is a research model where the roles between researchers and those researched are partly dissolved and where knowledge grows in dialogues between the people involved, rather than through information being transferred from information-givers to researchers. The distance between knowledge and action is short - elements of change/action are often combined with development of new knowledge. The model is particularly well suited in studies where experiences from actual life - the life-world - are sought. The collection of data by means of focus group interviews, particularly multistage focus groups, also means that these experiences are shared between the participants and can be the objects of reflection, development and deepening.

In this connection, social science theories on the long-term development of society, and structural concepts like 'risk society', 'disembedding' and 'individualisation' constitute starting points. Concepts that might be expected to be too intangible to be able to be operationalised and identified in an open discussion as in a multistage focus group. However, the main purpose of the study was not to contribute to the theory of late-modernity or the risk society. Instead the focus was on the everyday experiences of the participants and the extent to which they are connected with or differ from the distinctive features that characterize late-modern society. The everyday life of people with mental disabilities was the starting point against which the explanation value of the concepts could be discussed.

In spite of this, it appears that many of the concepts used to characterise late-modern society - or the risk society - can be identified by the participants and correspond well with their everyday life experiences with regard to content. Not surprisingly, the study also shows that other expressions are used to describe these experiences. The content of concepts like 'the disembedded society' could very well be recognised and described, while the concepts themselves could feel unfamiliar. At least two experiences with regard to method can therefore be noted: 
- That the study's bases in structural social-science theory can well be combined with the open participant-based and formative element in co-operative inquiry, and

- That structural concepts like these also have a broad explanation value in a discussion on concrete life experiences, i.e. the structural macro-level and the social micro-level could be successfully combined in this study.

We will now proceed to discuss the empirical results in relation to the earlier description of societal changes and changes in the way of regarding people with mental disabilities - and society's support of this group.

\subsection{Everyday life in late-modern society}

The results of the study have been reported in five comprehensive categories. The first of these - change and uncertainty - focuses on the rapid change in society, which means that social relations based on spatial closeness and long-term consideration tend to be replaced by anonymous, 'technified' and shorter-term relations. Giddens (1996) uses the concept 'disembedding' to describe just this process - that the relations are removed from their ontological context. The result tends to be anonymisation and alienation. 'Waiting music', which is common in shopping centres and telephone contacts, for example, can be viewed in the same perspective, as an anonymising sound barrier. For people who are strained by mental disabilities the result can be increased stress and concentration difficulties. One of the participants describes it as a "process of alienation". The rapid pace of change and demands for increased efficiency have the same effect. The conditions for spontaneous and informal meetings are reduced in a world in which membership of a limited local community is weakened.

Mental disabilities and societal obstacles is a category that focuses on the relation between the individual and society, primarily in nursing and medical care. The participants give examples of how their mental disabilities are made evident in various societal contexts, often in contacts with support and treatment professionals. Bureaucratic administrative routines, shortage of time and - once again - lack of a personal and long-term contact make societal contacts difficult and, paradoxically enough, can contribute to accentuating the mental disability instead of mitigating its consequences. "You don't get trust in eight different people. Trust must be built over time." This quotation illustrates Giddens' expression (1996) 'transformation of intimacy'. In contemporary society trust can be built on personal contacts to a lesser extent. But the quotation shows even more clearly the difficulty of trusting a system that seems impersonal and incomprehensible. The problems are also evident in the meeting with a society that in general demands more and more adaptation and streamlining, for example when it is a question of the possibility of getting a job and a reasonable income. Concepts like 'employability' indicate this development - it is the individual that is to be adapted to the labour market, not the other way round. A weak financial situation in combination with a great need of support and service, which often cost money, contribute even more to a feeling of being an outsider: "It is expensive to be poor."

The technical dominance is a prominent feature in late-modern society, as in the discussion about the risk society. Advanced computer technology and communication technology characterise practically every area of social life and for the individual. Knowing how to handle the technology and access to computers and mobile phones are regarded as more or less implicit conditions for a functioning everyday life. The participants in the study see several problems with this. For those who do not have access to a computer of their own and connection to the Internet it can be difficult to handle contacts with authorities and 
carers. Information via the Internet is often more difficult to understand than necessary, the participants would like to see the participation of users when web pages are set up. If one is familiar with the Internet and has access to modern computer equipment, on the other hand, the technology offers new possibilities. For those who can find face-to-face contacts difficult, particularly meeting groups of people, computer technology makes personal communication possible, but on their own terms; they can be close and distant at the same time. By means of a personal blog they can show the sides of themselves they wish, but at the same time keep other parts to themselves. Computer and information technology mean both limitations and advantages, but the negative aspects outweigh the positive ones. Up-todate knowledge is decisive - "If you lack knowledge you will easily be outside and powerless. If you have knowledge, you are inside."

The development towards increased individualisation can be traced over a long period of time and is not primarily caused by the rise of late-modern society. Nevertheless, the individualisation process is very clear in today's society, where both possibilities and responsibility rest to such a high degree on the individual. The participants' experiences in this area are summed up in the category Individualisation and loneliness. The possibilities to create and form one's own life have never been greater. Globalisation, unbounded technology, a higher level of education and a generally higher material standard of living are important factors here. Paradoxically enough, they also involve greater pressure on the individual to live up to various standards and fashions, at the same time as the demand to 'stand up for what you are' increases. It can be difficult to meet these apparently conflicting demands. A greater feeling of loneliness can therefore go with increased individualisation. The distance between people increases. The participants even think we have created a 'terror society': "... we are afraid of the neighbours and are sceptical towards them - the 'risk society' is marked by loneliness."

As is shown above, the characteristics of late-modern society can to a great extent be found in the everyday experiences of the participants. For the most part it is a question of the change in society involving an increase in problems and stress, which was also the fundamental assumption behind the study. For those who suffer from mental disabilities society has become more anonymous, 'depopulated', inaccessible, demanding and insecure. How much more natural then to seek new ways for fellowship and belonging. In the category Searching for a meaningful everyday life the focus is on two of the arenas of the world of life - working life and social network. Through the development of computer and communication technology new possibilities have been opened for adapting working life also to various forms of mental disability. However, for this to be possible those responsible must have the will to do so, and the participants experience that this is not always the case. Instead there is a tendency towards increased medication, something that can be "a chemical lid over what is difficult".

At least as important as having a job or something meaningful to do is belonging to a social community (which can naturally also be connected with a job). The participants in the study come from a user-steered centre connected to the user organisation Mental Health. The Centre provides the possibility of building up a new social network, having the feeling of belonging to a social community. The Centre is a 'free zone', members are met with trust and positive expectations, they support each other and show genuine care - "We mean it when we ask: How are you now?" It is not a question of a get-together without demands, but the demands are adapted to the person and the situation; one of the participants compared the Centre with a 'greenhouse' where everyone has the possibility for personal growth on their own premisses. 
The user organisation Mental Health and the activities in the Centre are examples of how people with mental disabilities (as one of several groups) have developed a greater degree of user organisation and user influence in recent years. Late-modern society leaves more freedom of choice and responsibility to the individual but also opens the way to new forms of organisation and support. In one sense this society leaves the individual to his own fate to a greater extent. The vision of the modern - industrial - society, of an all-embracing and united welfare society, can partly be regarded as having cracked. But in the cracks new possibilities open up. The activity at the Centre can be regarded as such an alternative organisation, an answer to the needs that societal development has created, but at the same time made possible.

The participants think that the larger society can learn something important from such alternative fellowships - like what the Centre represents. Some of the special characteristics here are the flexibility both in relation to organisation and content, and the positive balance between individual and collective focusing. Besides, the Centre has something to teach to others about different expressions of trust, mixture of age and gender and the tolerance for diversity which characterise the milieu. Being met with care and trust strengthens personal responsibility and the feeling of community. Such beneficial social relationships seem to promote recovery processes (Schön et al 2009). Public service systems could develop in a more user-friendly way if they were based to a greater extent on trust and shared responsibility instead of distrust accompanied by the need for control systems, namely, a welfare system in alliance with the users "focusing on supporting them to deal with the uncertainty that is a feature of late-modern society" (Börjeson 2005: 23).

\section{Possible ways forward, from the perspective of users, professionals, educators and researchers}

The purpose of the study was focused on experiences in everyday life of people with mental disabilities. They constitute a group that - like several others - can be regarded as exposed and vulnerable, and thus dependent on support from society, not least from mental health care and social support work. The question of everyday life in late-modern society for people with mental disabilities therefore does not concern only themselves but also several other groups: professionals in care and support activities, teachers and heads of higher education, and people working with research and development (R\&D). We therefore conclude the chapter with some ideas - visions - about continued development and the needs of change that can be regarded as called for in a society characterised by late modernity and new uncertainties. The tree groups we deal with are users (and user organisations), professionals and educators, and those working with R\&D.

\subsection{The role of service users and service users' organisations}

The process towards openness and participation in social life for people with mental disabilities that was started in connection with de-institutionalisation in the 1960s will continue. User perspective and user influence can be expected to be far more prominent than today. This is the case with regard to individual users, but to an even higher degree for various forms of organised co-operation between them.

Service users in the area of mental disabilities create and strengthen their own organisations and associations. These organisations consist in certain cases only of service users/former service users, while in others relatives, professionals in the field of mental disabilities and, in 
certain cases, others who wish to support the work can be members. In certain countries people with mental disabilities have, not least with inspiration from Italian examples, built up co-operative enterprises that provide income but also social support and belonging. Forming organisations of their own and increased user influence are themes that are gaining greater scope. Having experience of functional disorder or social failure oneself is gradually also becoming valued as an important competence from the perspective of society. With a continued and even more pronounced development in this direction, it also seems logical for user-led organisations to establish contacts and be organised over national borders. Service users' voices would then be more united and have a greater impact.

\subsection{The role of professionals and educators}

The societal changes in the late-modern countries and the development towards a risk society also have consequences with regard to professionals and higher education in this field. Care and support for people with mental disabilities can be expected to involve markedly changed professional roles. Being a professional does not always mean knowing best. The knowledge of service users (knowledge from experience) will in many cases be valued as equal in merit to the knowledge of professionals (theoretical knowledge and experiential knowledge). Definition power and decision power are to be shared between professionals and service users.

Academic programmes should prepare students for work where professionals are in alliance with service users to a far greater extent. Training must also give a preparedness to work together with other professions to a far higher degree than today. Knowledge on everyday-living - with shortcomings due to the mental disability taken into account - will be an increasingly important part of higher education. In mental health care the balance of power shifts from the scientific/medical perspective towards the sociological/humanistic perspective. The growing research on recovery processes points unequivocally to the importance of an ideographic approach to knowledge, where all aspects of a person (physical, mental, social, spiritual) have their justified space. Internationalisation, globalisation, a closer collaboration between countries and harmonisation in an increasing number of fields will demand training courses that add a regional and a European perspective to the local and national perspective.

\subsection{The role of Research and Development (R\&D)}

Research and the production of knowledge play an increasingly important role. The development of a risk society changes knowledge requirements. Research has a greater responsibility for developing and implementing knowledge that can be used in people's everyday lives. Research that is close to practice and linked to life environments and local communities can contribute to knowledge for coping with new risks and uncertainties. It will then also be natural for research and social change to be linked together in action research projects, for example by using the co-operative inquiry research model (Reason \& Heron 1986, Hummelvoll 2006). Service users, but also professional welfare workers, are more and more closely involved in research. Increasing needs, in combination with stagnating or diminishing resources, make greater demands on research to develop new forms of care and treatment, but also to point out deficiencies in forms of support that are out of keeping with the times, so that they can be phased out. The responsibility of research to contribute to society's development becomes increasingly clear. 


\section{References}

Beck, U. (1986) Risikogesellschaft: Auf dem Weg in eine andere Moderne. Frankfurt am Main: Suhrkamp Verlag.

Beck, U. (1992) Risk Society. Towards a New Modernity. London: Sage.

Beck, U. (1994) The reinvention of politics: Towards a Theory of Reflexive Modernization. In U. Beck, A. Giddens \& S. Lash (Eds.) Reflexive Modernisation. Politics, tradition and aesthetics in the modern social order. Oxford: Blackwell Publishers.

Beck, U. (1998) Politics of Risk Society. I J. Franklin (Red.) The Politics of Risk Society. Oxford: Polity Press.

Børjeson, M. (2005) Vi vet inte vilka metoder vi ska använda - om relationen mellan kunskap, praktik och politik när det gäller det sociala arbetet med hemlöshetsfrågor. Akademisk avhandling. Institutionen för socialt arbete. Stockholm: Stockholms universitet.

Eliasson, R-M. \& Nygren, J. (1981) Utvärdering av psykiatrisk verksamhet. Del I. Stockholm: Prisma.

Eriksson, B.G. \& Hummelvoll, J.K. (2011) To live as mentally disabled in the risk society. Journal of Psychiatric and Mental Health Nursing, In press.

Forsberg, E. (1992) The 'long-term mentally ill'. I P-G. Svensson och B. Starrin (Eds.) Health policy development for disadvantaged groups. Oslo: Scandinavian University Press.

Forsberg, E. (1994) Den stora utflyttningen - studier av psykiatrins omvandling. Rapport 1994:3.

Foucault, M. (2006) History of Madness. London: Routledge.

Granerud, A. \& Severinsson, E. (2006) The struggle for social integration in the community the experiences of people with mental health problems. Journal of Psychiatric and Mental Health Nursing 13, 288-293.

Harste, G. (1999) Postindustrialism, kulturkritik och risksamhälle. I H. Andersen \& L. B. Kaspersen (red.) Klassisk och modern samhällsteori. Lund: Studentlitteratur.

Hummelvoll, J.K. (2006) Handlingsorientert forskningssamarbeid - teoretisk begrunnelse og praktiske implikasjoner. Norsk Tidskrift for Sykepleieforskning, 8:1, 17-30

Hummelvoll, J.K. (2008) The multistage focus group interview - a relevant and fruitful method in action research based on a co-operative inquiry perspective. Norsk Tidsskrift for Sykepleieforskning, 10(1): 3-14.

Hummelvoll, J.K., Eriksson, B.E. \& Beston, G. (2009) Mennesker med psykiske funksjonshindringer $i$ risikosamfunnet - en hverdagsnær tilnærming. Elverum: Høgskolen i Hedmark, Rapport no. 13.

Malterud, K. (2003) Kvalitative metoder $i$ medisinsk forskning. En innføring. Oslo: Universitetsforlaget.

Reason, P. (1994) Three Approaches to Participative Inquiry. In: N.K Denzin \& Y.S. Lincoln (eds.). Handbook of Qualitative Research. London: Sage Publications.

Reason, P. \& Heron J. (1986). Research with people: The paradigm of co-operative experiential inquiry. Person Centered Review, 1: 456-475.

Rowan, J. (2006) The Humanistic Approach to Action Research. In: P. Reason \& H. Bradbury (eds.). Handbook of Action Research. London: SAGE Publications. pp 106-116.

Scheff, T. J. (1966) Being Mentally Ill: A Sociological Theory. Chicago: Aldine.

Schön, U-K., Denhov A. \& Topor A. (2009) Social relationships as a decisive factor in recovering from severe mental illness. International Journal of Social Psychiatry 55, 336-347. 
Svensson, T. (2005) Psykiatri eller inte? Radikal psykiatrikritik undere 1960 och 1970-talen. I L-C. Hydén (Red.) Från psykiskt sjuk till psykiskt funktionshindrad. Lund: Studentlitteratur.

Szasz, T. (1961) The Myth of Mental Illness. New York: Hoerber-Harper.

World Medical Association (2002) The Declaration of Helsinki (document 17C). Retrieved 15.11.04, 2004. 


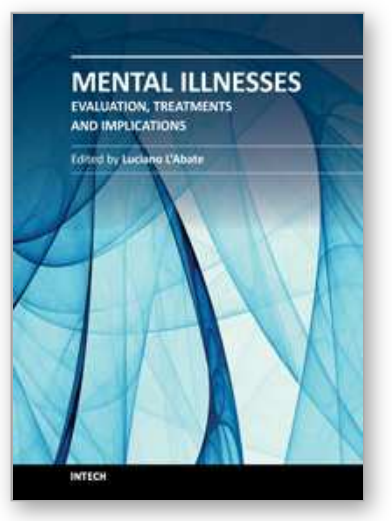

\author{
Mental IIInesses - Evaluation, Treatments and Implications \\ Edited by Prof. Luciano LAbate
}

ISBN 978-953-307-645-4

Hard cover, 476 pages

Publisher InTech

Published online 13, January, 2012

Published in print edition January, 2012

In the book "Mental Illnesses - Evaluation, Treatments and Implications" attention is focused on background factors underlying mental illness. It is crucial that mental illness be evaluated thoroughly if we want to understand its nature, predict its long-term outcome, and treat it with specific rather than generic treatment, such as pharmacotherapy for instance. Additionally, community-wide and cognitive-behavioral approaches need to be combined to decrease the severity of symptoms of mental illness. Unfortunately, those who should profit the most by combination of treatments, often times refuse treatment or show poor adherence to treatment maintenance. Most importantly, what are the implications of the above for the mental health community? Mental illness cannot be treated with one single form of treatment. Combined individual, community, and socially-oriented treatments, including recent distance-writing technologies will hopefully allow a more integrated approach to decrease mental illness world-wide.

\title{
How to reference
}

In order to correctly reference this scholarly work, feel free to copy and paste the following:

Bengt Eriksson and Jan Kåre Hummelvoll (2012). Coping and Meaning in Everyday Life: Living with Mental Disabilities in Late-Modern Society, Mental Illnesses - Evaluation, Treatments and Implications, Prof. Luciano LAbate (Ed.), ISBN: 978-953-307-645-4, InTech, Available from: http://www.intechopen.com/books/mentalillnesses-evaluation-treatments-and-implications/coping-and-meaning-in-everyday-life-living-with-mentaldisabilities-in-late-modern-society

\section{INTECH}

open science | open minds

\section{InTech Europe}

University Campus STeP Ri

Slavka Krautzeka 83/A

51000 Rijeka, Croatia

Phone: +385 (51) 770447

Fax: +385 (51) 686166

www.intechopen.com

\section{InTech China}

Unit 405, Office Block, Hotel Equatorial Shanghai

No.65, Yan An Road (West), Shanghai, 200040, China

中国上海市延安西路65号上海国际贵都大饭店办公楼 405 单元

Phone: +86-21-62489820

Fax: $+86-21-62489821$ 
(C) 2012 The Author(s). Licensee IntechOpen. This is an open access article distributed under the terms of the Creative Commons Attribution 3.0 License, which permits unrestricted use, distribution, and reproduction in any medium, provided the original work is properly cited. 